\section{The Planet Mercury}

By Dr. Werner Sandner. Translated by Alex Helm. Pp. $94+11$ plates. (London: Faber and Faber, Ltd., 1963.) 218. net.

NY author who undertakes to write an entire book A about the planot Mercury is handicapped by the paucity of material. Mercury, the innermost planet, never lies farther than $28^{\circ}$ from tho Sun and is consequently a difficult planot to observe. Its diameter at the time most favourable to observation is only about $8 \mathrm{sec}$ of arc, so fairly large telescopes are noeded to accumulate knowledgo of tho surface details. Large telescopes are rarely used for planetary observation.

Werner Sandner has summarized what is known about Mercury in this well-presented little book. $\mathrm{H}_{\Theta}$ has expanded his material by giving historical annotations and by a certain amount of repetition. Thus, for example, practically all of Chapter 12 (which consists of one-and-ahalf pages of print) has appeared in earlier ehapters. Sandner has covored his subject well, including the fow recent developments. There would appear to be some misplaced emphasis on certain observers; not enough is said about the work of Antoniadi and Jarry-Desloges, working with large instruments and under excellent conditions respectively, and too much space is devoted to modern amatours working with very small tolescopes.

The Planet Mercury is one in a series of books devoted to objects in the Solar System. This series has turned out rather inhomogoneous. On one hand we have the books on Jupiter, Mars and the Sun which are written in a scientifie vein, and on the other those on Venus and Saturn which contain a wealth of historical and bibliographical data. The book under review tends towards the lattor style, but cannot claim to be so authoritative or so permanent as its fellows in this series. As a general knowledge book it is extremely readable, but it is unlikely to furnish a contribution to lasting texts on the Solar System.

Brian WarNer

\section{Kempe's Engineers Year Book}

70th odition. Edited by C. .E. Prockter under the direction of B. W. Penred. Vol. 1, pp. xiv +1340 . Vol. 2, pp. viii + 1399. (London: Morgan Brothers (Publishers), Ltd., 1965.) 92s. 6d.

$$
7
$$
HIS seventieth edition of Kempe's Engineers Year Book is much the same as the previous two editions for 1963 and 1964, respectively. It contains useful data relevant to all the major branches of engineering and descriptive matter on enginoering works, plant, equipment, processes and instrumentation, with references to original sources. There is one new chapter dealing with plain bearings, and thore are a fow important additions to other chapters. The inclusion now of information on electroslag welding, carbon dioxide welding, plasma are cutting and friction wolding is particularly noteworthy as are the new data on polymer cement admixtures, details of timing devices and fire extinguishers and fire precautions in high buildings. The chapter on depreciation which was revised previously to take account of the provisions of the Finance Act, 1963, will presumably receive further attention in the future in the light of changes introduced by the new Governmont.

Thoro appears to be some reluctance to replace out-ofdate material. Thus, the sections on theory and design of steel structures elearly belong to the ora betwoen the wars, in spite of the fact that tables of new universal steel sections and details of steel to B.S.968 are included. Modern criteria of design of stool structuros based on ultimate load-carrying capacity and details of welded and bolted construction with joints of full rigidity are again omitted. It is, incidentally, intoresting to see that the reciprocating steam ongine and Lancashire boiler still have a place in this book and that there is a chapter on railway steam locomotivos.
In spite of some grounds for criticism, the appearance of this new edition of Kempe's Engineers Year Book will be welcomed by the engineering profession generally, for, besides its usefulness in providing essential data, it is something of an 'armchair' guide to engineering. The time is probably approaching, though, when it would benefit by some reappraisal of its objectives in view of the rapidly changing scene of engineering.

\section{T. M. Charliton}

\section{Physical Electronics}

By Dr. C. F. Alfrey. Pp. 220. (Princeton, N.J.: D. Van Nostrand Company, Inc.; London: D. Van Nostrand Company, Ltd., 1964.) Paperbound 27s. 6d.; Clothbound $50 s$.

R. G. F. ALFREY'S book is concerned with the foundations of physical electronics, covering in its fifteen chapters a considerable field in an essentially descriptive fashion. Detailed mathematical analysis is largoly absont from the work, and Dr. Alfrey draws on theoretical results relovant to each of the topics treated. In this way he is able to concentrate on tho physical significanco of these results in progressively building up a coherent picture of his subject.

Essential quantum mechanical concepts aro introduced at an oarly stage, and used to explain the basic chemical behaviour of complex atoms. Thereafter, however, the quantum theory is introduced only when adequate physical pictures cannot be developed in terms of classical theory. After the opening chapters the first half of the book is devoted to electrons in gases and in vacuo, and includes clectron omission, electron opties, vacuum and gas-fillod devices and plasma applications. Eloctrons in solids are discussed in the later chapters, which deal with conduction, semi-conducting devices, magnetic and dielectric properties, noise and molecular amplification.

Despite the wide range of subject matter, the author has achioved, through this qualitative approach, a treatment of the subject which has a unity not usually evident in weightier and more analytical works. The volume will surely be welcomed as a student text-book for undergraduate courses where no similar book has existed before, and will serve equally well as an introduction to those wishing later to make a more complete study of the subject.

E. M. Deeley

The World of Learning, 1964-65

Fifteenth edition. Pp. xiv + 1502. (London: Europa Publications, Ltd., 1964.) 140s. net.

"A DIREC'TORY of the world's universities, collegos, A learned societics, libraries, museums, art galleries and research institutes", this indispensable roference volume is unchanged in form and lay-out, but has been brought up to date. The increaso in the number of institutions is reflected in the length of the main section of the volume, which occupies some 70 pages more than the edition of a year ago. It should be noted that the price has not been increased. As before, tho introductory section is dovoted to a description of the aims and functions, the organization and the budget of the United Nations Educational, Scientific and Cultural Organization (Unesco). This section, which has also been brought up to dato, is followed by briof accounts of the international organizations (the International Council of Scientific Unions, the International Council for Philosophy and Humanistio Studies, and othors). The main body of the volume is arranged by countries, of which thoro are 158. Tho countries are listed alphabetically in the list of contents; tho main index is basod on tho names of institutions. Unfortunately there is no index of individuals; although the volume can only accommodate the names of senior staff, it includes several thousand names, with the subjects for which they are responsible, and an index to them would onhance the usefulness of the directory 